\title{
Adrenaline Reversal in Intestinal Smooth Muscle
}

By

\author{
Taizo Suzuki, Akinori Nishiyama and Kazuo Shishido \\ Department of Applied Physiology, Tohoku University, \\ School of Medicine, Sendai
}

(Received for publication, June 10, 1962)

\section{INTRODUCTION}

As is well known, the sympathetic nerve stimulation has an excitatory action on some visceral smooth muscle and an inhibitory action on the others. But, as many investigators have pointed out before, the pure excitatory and inhibitory effects of nerve stimulation are rather exception and the response of a visceral smooth muscle to nerve stimulation was often variable. Hitherto, no particular attention has been paid to such a variable response, because it is accepted that the extrinsic nerve of the viscera contains excitatory as well as inhibitory fibers and the response to nerve stimulation is determined by the predominant fiber. Dale ${ }^{1)}$ reported that, in the presence of ergot, a motor effect could be converted into an inhibitory one. He believed that the inhibitory effect was always present, but, normally, it is obscured by the predominant fiber. Kennard ${ }^{2)}$ assumed that the excitatory and inhibitory responses by nerve stimulation are due to the formation of two kinds of transmitter substances liberated in a smooth muscle.

However, these speculations of dual sympathetic innervation or two kinds of transmitter do not seem to account for the fact that, sometimes, excitatory as well as inhibitory responses are produced in the same organ by adrenaline alone. Bozler $^{3)}$ reported that the response of intestinal and uterine muscles to adrenaline were variable, often diphasic and reverse according to the condition of muscle.

The present study was undertaken to find out the condition of muscle cell in which the mechanical response of intestinal smooth muscle to adrenaline is reverse.

\section{METHODS}

Rabbtis, weighing 2.5 to $3.5 \mathrm{~kg}$, were used for experiments. They were killed with ether. Opened the abdomen, tied off the duodenum, freed a loop about $15 \mathrm{~cm}$. long and stocked in normal Krebs solution. A strip cut from a loop was mounted in a plastic chamber, oxygenated the solution, keeping the temperature constant $\left(36^{\circ} \mathrm{C}\right)$. One end of muscle strip was tied to a plastic lever with

鈴木泰三，西山明德，宾戸和夫 
minimum friction which transmitted the tension to the strain gauge transducer (Grass FT-10). The transducer in turn was connected, through a DC amplifier, to the ink writing oscillograph (Grass Polygraph V). In this way, the isometric tension of intestinal smooth muscle was recorded.

In some experiments, $\mathrm{NaBr}-\mathrm{Krebs}$ solution $(\mathrm{NaCl}$ in $\mathrm{Krebs}$ solution was replaced by $\mathrm{NaBr}$ ), choline-Krebs solution ( $\mathrm{NaCl}$ was replaced by choline chloride), TeaCl-Krebs solution ( $\mathrm{NaCl}$ was replaced by tetraethylammonium chloride) and LiCl-Krebs solution ( $\mathrm{NaCl}$ was replaced by $\mathrm{LiCl}$ ) were used to observe the action of adrenaline in the absence of $\mathrm{Na}$ or $\mathrm{Cl}$ ion from the media.

\section{RESULTS}

The effect of adrenaline on the depolarized intestinal smooth muscle: When adrenaline $\left(10^{-8}\right)$ was applied to the muscle strip in normal Krebs solution, the spontaneous rhythmic activity disappeared and sustained relaxation was obtained. However, at weaker concentration of adrenaline, muscle strip recovered from relaxation to normal state immediately (Fig. 1). If adrenaline was applied
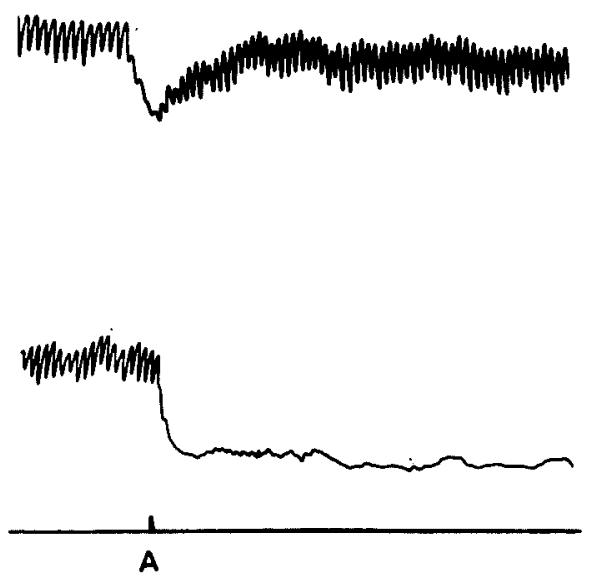

Fig. 1. The effect of adrenaline in normal Krebs solution. Above: low concentration of adrenaline $\left(2 \times 10^{-7}\right)$. Below: high concentration of adrenaline $\left(2 \times 10^{-6}\right)$.

to the preparation which has been depolarized previously by increasing the concentration of $\mathrm{K}$ in solution, the relaxing effect became gradually less than those in normal solution, until the effect of adrenaline was, in most cases, reversed (adrenaline reversal). That is, adrenaline acts on the intestinal smooth muscle to contract. The threshold concentration of $\mathrm{K}$ for this adrenaline reversal depends largely upon the condition of muscle, and under normal condition, it is about 10 $\mathrm{mM} \mathrm{K}$. When the muscle strip was further depolarized step by step by increasing 
the potassium concentration in solution, the contractile response to adrenaline first increased, but then decreased. That is, adrenaline reversals occur in some range of $\mathrm{K}$ concentration and this range also depends on the condition of muscle strip. In normal condition, it ranged from 10 to $18 \mathrm{mM} \mathrm{K}$ (Fig. 2). When adrenaline was applied to the muscle strip which is previously immersed in isotonic $\mathrm{K}_{2} \mathrm{SO}_{4^{-}}$ Krebs solution to make the cell membrane depolarized completely, muscle strip responded to relax. This fact confirmed the finding of Evans et al. ${ }^{4}$ )

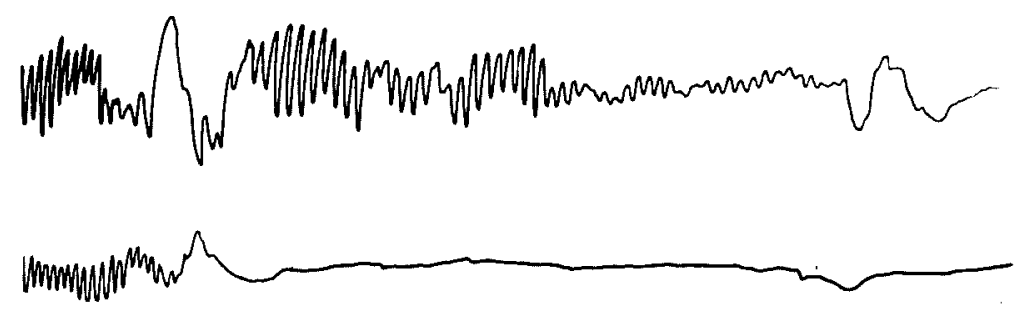

Fig. 2. The effect of adrenaline in a solution containing high potassium. Above: $14 \mathrm{mM} \mathrm{K}$. Below: $20 \mathrm{mM} \mathrm{K}$.

The effect of adrenaline in NaBr-Krebs solution: When adrenaline (10-8) was applied to the muscle strip which was immersed in NaBr-Krebs solution, the relaxing response was observed but less effective (Fig. 3). If potassium concentration in $\mathrm{NaBr}-\mathrm{Krebs}$ solution was increased by adding $\mathrm{KCl}$, adrenaline reversal was produced. The threshold concentration of $\mathrm{K}$ for adrenaline reversal in $\mathrm{NaBr}$-Krebs solution was lower than in normal $\mathrm{NaCl}-\mathrm{Krebs}$ solution. This means, as far as adrenaline reversal is concerned, $\mathrm{NaBr}-\mathrm{Kr}$ rebs solution behaves to the intestinal smooth muscle as $\mathrm{NaCl}-\mathrm{Krebs}$ solution with slightly higher concentration of K (Fig. 4). The present authors confirmed this fact with intracellular microelectrode that the membrane potential became depolarized slightly by immersing a strip in $\mathrm{NaBr}-\mathrm{Krebs}$ solution (unpublished observation ${ }^{10}$ )).

In $\mathrm{NaBr}-\mathrm{Krebs}$ solution containing adequate concentration of $\mathrm{K}$, the double application of adrenaline brought about the double response of contraction (Fig. 5).

The effect of adrenaline in choline-Krebs solution: In choline-Krebs solution, the muscle strip contracted by adrenaline (Fig. 6).

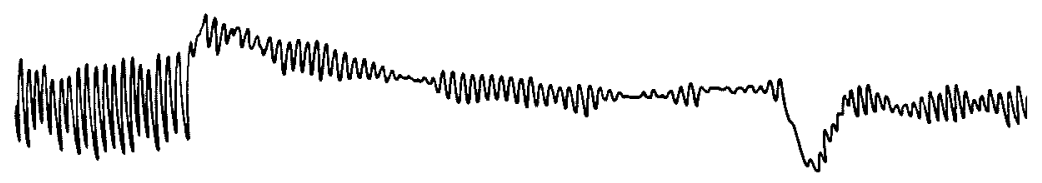

Fig. 3. The effect of adrenaline in $\mathrm{NaBr}-\mathrm{Krebs}$ solution (3.2 $\mathrm{mM} \mathrm{K})$. 
A
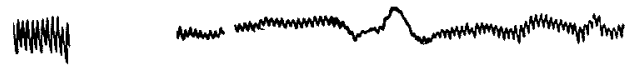

8

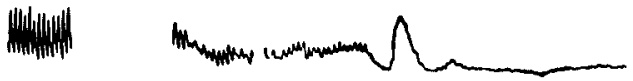

C

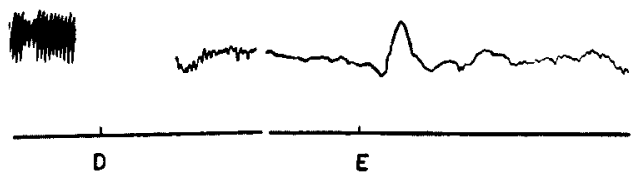

Fig. 4. The effect of adrenaline in $\mathrm{NaBr}-\mathrm{Krebs}$ solution containing high potassium. A: $6 \mathrm{mM} \mathrm{K}$. B: $9 \mathrm{mM} \mathrm{K}$. C: $12 \mathrm{mM} \mathrm{K}$. D: substitution of $\mathrm{NaBr}$ Krebs solution with high potassium for NaCl-Krebs solution. $\mathbf{E}$ : application of adrenaline.

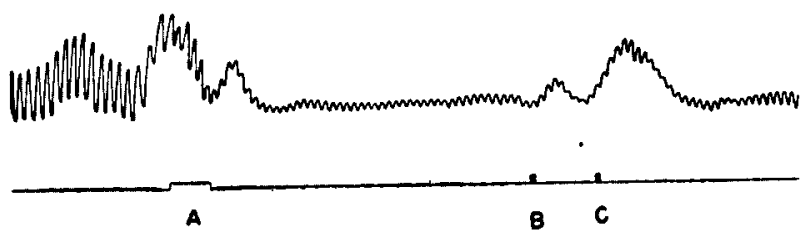

Fig. 5. Double response to adrenaline. A: substitution of $\mathrm{NaBr}-\mathrm{Krebs}$ solution with high potassium for normal Krebs solution. B and C: application of adrenaline.

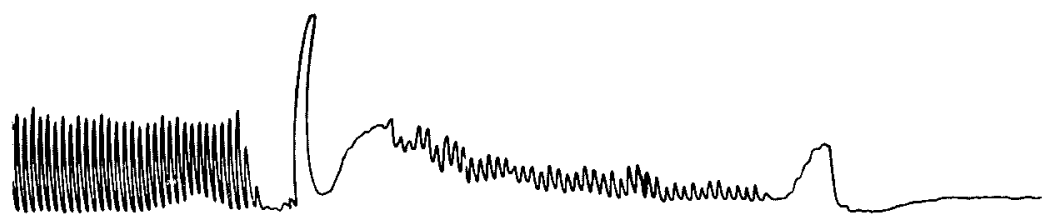

Fig. 6. The effect of adrenaline in choline-Krebs solution.

The effect of adrenaline in TEACl-Krebs solution and LiCl-Krebs solutions: The adrenaline reversal was also produced in the muscle strip which was immersed in TEACl-Krebs solution. But this reversal was only observed in partial TEACl-Krebs solution (in this experiment, 1,3 of $\mathrm{NaCl}$ was replaced by $\mathrm{TeACl}$ ) and not in total TEACl-Krebs solution (Fig. 7).

Adrenaline reversal was also observed in partial LiCl-Krebs solution. 

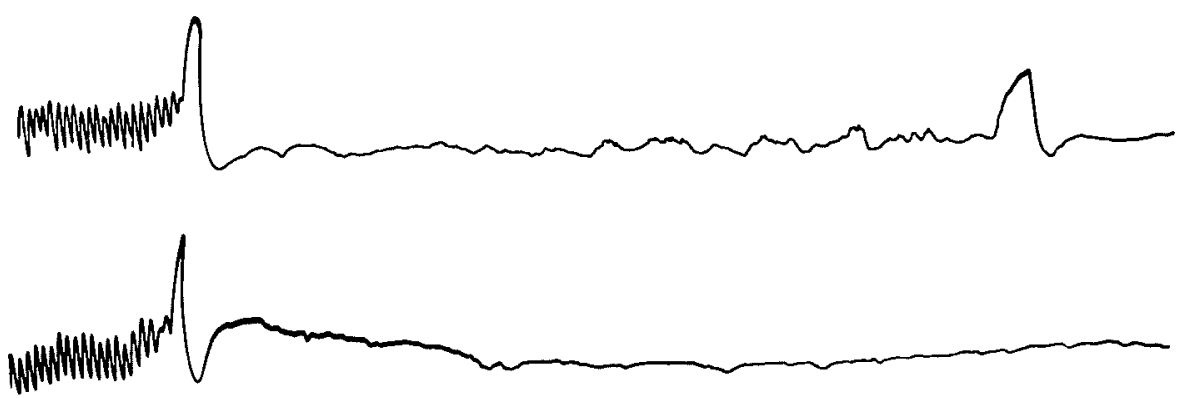

Fig. 7. The effect of adrenaline in TEACl-Krebs solution. Above, partial TEAClKrebs solution; below, total TEACl-Krebs solution.

\section{DISCUSSION}

In discussing the mechanism by which adrenaline reversal is presented, it is most acceptable that the whole process of mechanical response to adrenaline is divided up in three consecutive steps, namely (1) the adrenergic receptor, (2) the excitation system in muscle cell membrane and (3) the contractile system in muscle cells.

(1) Adrenergic receptor: The concept of receptor has been proposed and tested by many pharmacologists for many years and recently Furchgott ${ }^{5}$ ) proposed the four adrenergic receptors in smooth muscle; $\alpha, \beta, \gamma$ and $\delta$ receptors. The receptor theory would be of considerable help in defining the intricate mechanism of drug-interactions in smooth muscle, and by this theory, adrenaline reversal would be explained to be the result of the change of predominance among those receptors. But, virtually, nothing is known about the actual nature of adrenergic receptors, it is impossible to add further discussion on the kinetics of adrenaline reversal at receptor level.

(2) The excitation system in cell membrane: It is most probable that the condition of membrane activity is responsible for adrenaline reversal. Burnstock $^{6,7)}$ reported the interesting fact that Ach produced the contractile response in taenia coli in normal solution, but after prolonged exposure to high $\mathrm{K}$ solution $(40 \mathrm{mM})$, the response was reversed (Ach-reversal). He suggested the following hypothesis in which the differential permeability of cell membrane to $\mathrm{Na}$ and $\mathrm{K}$ altered by high $\mathrm{K}$, so that the hyperpolarizing influence of $\mathrm{K}$ efflux became greater than the depolarizing influence of $\mathrm{Na}$ influx; or Ach reset the membrane potential and shifted it towards on the new equilibrium level. Present authors have shown with intracellular microelectrode that the membrane potential became depolarized when it is immersed in $\mathrm{NaBr}$-, LiCl-, TeACl-, or choline-Krebs solutions, and that when adrenaline was applied to the strip which was immersed previously in LiCl-Krebs solution, marked depolarization was observed, though 
it was preceded by a slight hyperpolarization (unpublished observation ${ }^{10}$ ). Those results are certainly in accord with the concept that adrenaline reversal results from a condition of membrane activity ${ }^{8}{ }^{89}$ But further work is required to analyse the mechanism by which adrenaline reversal is presented.

(3) Contractile system in muscle cell: As mentioned above, the muscle strip, when it is depolarized completely, still gives the relaxation. This indicates that adrenaline reversal could not be in accord with the direct action of adrenaline to contractile system.

\section{SUMMARY}

1. Isolated smooth muscle strip from rabbit intestine was used for measuring the isometric tension to observe the effect of adrenaline on the depolarized smooth muscle.

2. Under normal condition, adrenaline causes the relaxation, but by increasing the concentration of $\mathrm{K}$ in Krebs solution, this relaxing effect became gradually less, until the effect of adrenaline was reverse. This reversal was obtained only in a narrow range of $\mathrm{K}$ concentration.

3. In solution of higher concentration of $\mathrm{K}$, adrenaline caused the relaxation again.

4. Similar stimulant action of adrenaline was observed in muscle strip which has been immersed in $\mathrm{NaBr}-$, TeACl-, LiCl- or choline-Krebs solutions.

5. It is suggested from these results that, as far as mechanical response of smooth muscle is concerned, adrenaline has a single action and the direction of response to adrenaline is determined by the functional condition of the muscle cell membrane.

This work was aided by the Grant (GA BMR 5693) from the Rockefeller Foundation to one of the authors (T. Suzuki).

\section{References}

1) Dale, H.H., J. Physiol., 1906, 34, 163.

2) Kennard, J.H., Amer. J. Physiol., 1937, 118, 186.

3) Bozler, E., Amer. J. Physiol., 1940, 130, 627.

4) Evans, D.H.L., Schild, H.O. \& Thesleff, S., J. Physiol., 1958, 143, 474.

5) Furchgott, R.F., Pharmacol. Rev., 1959, 11, 429.

6) Burnstock, G., J. Physiol., 1958, 143, 169.

7) Burnstock, G., J. Physiol., 1958, 143, 183.

8) Axelsson, J. \& Bülbring, E., J. Physiol., 1961, 156, 344.

9) Axelsson, J., Bueding, E. \& Bülbring, E., J. Physiol., 1961, 156, 357.

10) Suzuki, T. \& Nishiyama, A., in preparation. 